\title{
Mites Inhibiting Guava Trees and Their Dynamics in Relation to Weather Factors and Plant Phenology
}

\author{
A. S. El-halawany and M. M. Abou-Setta \\ Plant Protection Research Institute, ARC, Dokki, Giza, Egypt
}

\begin{abstract}
Surveying mites associated with guava trees (Psidium guajava L.) at Qalyoubia governorate, Egypt indicated the occurrence of main five ones (i.e. the eriophyid, Tegolophus guavae (Boczek), the tenuipalpid, Brevipalpus phoenicis (Geijskes), the tetranychid, Tetranychus urticae Koch, the phytoseiid, Amblyseius swirskii A.-H. and the stigmaeid, Agistemus exsertus (Gouzalez)). Other six species were present in low numbers. The population dynamics of the main ones in relation to weather factors and guava plant phenology were discussed. Populations of T. urticae peaked in midJun. and Oct. as 183.56 and 172.94 motile stages/leaf, respectively. B. phoenicis was observed at high population level in Jun. and Jul. on fruits and leaves, respectively. T. urticae population peaked in Jun. T. guavae preferred the east side of the tree. Significant relation occurred between mite's populations and temperature increases; while the relation with relative humidity was not significant. The dynamics of the phytophagous mites' population densites (as second trophic level) seemed to follow the plant phenology (specially the leaves). That of the predacious mites seemed to follow their prey dynamics with lag of time. T. guavae population was more significant on upper tree level than middle followed by the lower one. Younger leaves and lower surface were preferred to this mite than older ones and upper surface.
\end{abstract}

Key Words: Guava, Weather factors, Plant phenology, Population dynamics, Tegolophus guavae.

\section{INTRODUCTION}

Guava Psidium guajava L. (Murtacae) is widely grown all over the tropics and subtropics. Guava was introduced to Egypt during 1825 from India. Recently guava area in Egypt is about 40,000 acres producing about 340,000 tons of fruits (with an average productivity of 9.37 tons per acre) according to Egyptian Ministry of Agriculture Statistics (2011). Guava fruits possess high nutritional and medical values. Its fruits considered as the Poor's man apple of tropics. Guava is known to have tolerance to drought and high water salinity. It is perennial evergreen trees with unique flush pattern. It sheds most of its old leaves at early season of growth (during Feb.) and produce new foliage followed by flowers and subsequently fruit crop.

Studies on phytophagous mites inhabiting guava in Egypt are rare. Recently the eriophyid, Tegolophus guavae (Boczek) was recorded for the first time on guava leaves in Qalyoubia governorate, Egypt (El-Halawany, 2012). In Florida, USA, T. guavae and Brevipalpus spp., cause damage to fruits and tender leaves. Highest numbers of $T$. guavae were observed in early autumn, through winter and during spring months. These mites were most often observed on fruit, causing deformations (Pena et al., 1999).

Tegolophus hassani (Keifer) was reported on olive trees preferring the immature leaves to mature ones. It had one peak in mid Jul. The population was positively correlated with prevailing temperature and relative humidity. Positive relationships were also detected between the eriophyid species and their predators of prevailing phytoseiid and stigmaeid mites (Abou-Awad et al., 2005).

The tenuipalpid, Brevipalpus phoenicis (Geijskes) is an important pest of more than 50 plant genera. It is evidently well distributed throughout the world. This mite transmits leprosies virus when population is high (Jeppson et al., 1975). $B$. phoenicis was reported as principal of citrus (Zaher, 1984). Other hosts included guava, quince, sweet potato and acalypha. Ghoshal et al., 2011 found that on guava the tenuipalpid mite Tenuipalpus pernicis (Chaudhuri, Akbar and Rasool) peaked during May when mean temperature and R.H. were $31.28{ }^{\circ} \mathrm{C}$ and $72.62 \%$, respectively. The correlation coefficient of the mite density with temperature was positive; while with R.H. was nonsignificant.

The aim of this work was to monitor mite species inhabiting guava trees in Egypt and their population dynamics in relation to weather factors and plant phenology.

\section{MATERIALS AND METHODS}

An area of four acres Othmani guava variety, at Tanan village, Qalyoubia governorate was selected for this study. Trees were of four years old. Monitoring continued from Feb. 2012 to Jan. 2013.

Forty leaves representing the four cardinal 
direction, as well as leaf age were monthly examined as upper and lower surface. Also, fruit samples were picked up randomly as 20 fruits twice monthly when fruits were available. For tree levels, a monthly sample of 40 leaves presented each tree level were picked up. The lower level, was up to $1 \mathrm{~m}$ from soil surface, the middle, was at $1-1.5 \mathrm{~m}$ from soil surface and the top level was at more than $1.5 \mathrm{~m}$.

Monthly average minimum and maximum temperatures $\left({ }^{\circ} \mathrm{C}\right)$ and average relative humidity (R.H.) prevailing in the area during the study, were recorded.

Simple correlation was used to correlate between weather factors and average monthly number of mites. Two-way analysis of variance (ANOVA) and mean comparison using LSD were conducted for tree direction, tree levels, leaf age and surface. Analyses were conducted using SAS statistical software (SAS Institute, 2010).

\section{RESULTS AND DISCUSSION}

\section{Survey study:}

Obtained results of phytophagous and predacious mites of guava at Qalyoubia governorate are presented in Table (1). Results indicated the occurrence of eleven species. Three were phytophagous mites on leaves (i.e $T$. guavae (Boczek); B. phoenicis (Geijskes) and T. urticae Koch). B. phoenicis occurred also on fruits. Five predacious mites were recorded (i.e. Amblyseius swirskii (A.-H.), Amblyseius enab (El-Badry), Euseius scutalis (A.-H.) (Phytoseiidae); Agistemus exsertus Gonzalez (Stigmaeidae); Neophyllobius gonzali Zaher \& Gomaa (Camerobiidae)) in association with phytophagous ones. Three miscellaneous feecing habits species (i.e. Tarsonemus smithi Ewing (Tarsonemidae), Tydeus californicus Banks (Tydeidae) and Siculobata sicula Grandjean (Oribatidae)) were present (Table 1). These results agree with those reported by Jeppson et al., (1975); Zaher and Gomaa, (1979); Zaher, (1984); Pena et al., (1999) and El-halawany, (2001 \& 2012).

\section{Population dynamics of main mite fauna on guava: \\ Phytophagous mites:}

Obtained mean monthly populations of main phytophagous, predacious mites and related weather factor are illustrated at Fig. (1). Seasonal abundance of the guava rust mite $T$. guavae (the main phytophagous species) was studied for one year from Feb. 2012 to Jan. 2013. This mite appeared during the third week of Feb. 2012, when max and min temperatures and average R.H. were 18.69 \& $9.72^{\circ} \mathrm{C}$ and $49.21 \%$, respectively. The population started to increase until reaching the first peak on 15 Jun. (183.56 motile stages/leaf) at max and min temperatures $35 \& 22.5^{\circ} \mathrm{C}$ and average $49.57 \%$ R.H. The population then decreased form Jul. to Sep. 2012 followed by a sharp increase to the second peak on 15 Oct. (172.94 motile stages/ leaf) at max and min temperatures of $30.42 \& 20.71^{\circ} \mathrm{C}$ and average $59.9 \%$ R.H. The population gradually decreased in numbers from mid Nov. to mid Jan. 2013. The population responded to temperature increase with highly significant positive correlation value of 0.72 ; while R.H. had non-significant positive effect (Table 2).

Injury of guava caused by $T$. guavae at high population density seems rusting leaves or causes a pimple like response on the fruit epidermis (Pena et al., 1999). Similar results for the fig bud mite Aceria ficus Cotté. It had two annual peaks in Jun. and in Oct. on fig trees (El-Halawany, 2001).

The tenuipalpid B. phoenicis was recorded on leaves and fruits as the second main phytophagous mite. This mite appeared on leaves with few numbers in mid Mar. then gradually increased until mid Jul. with average ( 9.8 motile stages/leaf) at max. and min. temperatures of $35.6 \& 24.52^{\circ} \mathrm{C}$ and average $54.7 \%$ R.H. The population gradually decreased from Aug.-Sept. to reach zero motile stages /leaf in Oct.

B. phoenicis was recorded on fruits in mid-May reaching maximum numbers at the end Jun. with average numbers (12.15 motile stages/fruit), then gradually decreased until end Aug., when fruits were harvested.

Statistical analysis presented in table 2 showed highly significant positive correlation between temperature and population; while non significance with R.H. on leaves and fruits. Similar results of $T$. pernicis on guava were found by Ghoshal et al., (2011).

The two-spotted spider mite $T$. urticae was recorded in moderate numbers on leaves. It appeared in few numbers in Mar. then increased until mid Jun. and gradually decreased from Jul. to Oct. (Fig. 1). There was highly significant positive correlation between its population and temperature, while nonsignificant with R.H. on leaves. These results are relatively similar to those reported by El-Halawany, (2001) for T. urticae on pear and fig trees 
Table (1) List of mites inhabiting guava trees in Qalyoubia governorate

\begin{tabular}{lllc}
\multicolumn{1}{c}{ Family } & \multicolumn{1}{c}{ Scientific name } & Habitat & Abundance \\
\hline Eriophyidae Nalepa & Tegolophus guavae (Boczek) & Leaves & +++ \\
\hline Tenuipalpidae Berlese & Brevipalpus phoenicis (Geijskes) & Leaves \& fruits & +++ \\
\hline Tetranychidae Donnadieu & Tetranychus urticae Koch & Leaves & ++ \\
\hline Phytoseiidae Berlese & Amblyseius swirskii (A.-H.) & Leaves & +++ \\
\hline & Amblyseius enab (El-Badry) & Leaves & + \\
\hline & Euseius scutalis (A.-H.) & Leaves & + \\
\hline Stigmaeidae Oudemans & Agistemus exsertus Gonzalez & Leaves \& fruits & +++ \\
\hline Camerobiidae Southcott & Neophyllobius gonzali Zaher \& Gomaa & Leaves & + \\
\hline Tarsonemidae Kramer & Tarsonemus smithi Ewing & Leaves \& fruits & + \\
\hline Tydeidae Kramer & Tydeus californicus Banks & Leaves & + \\
\hline Oribatidae Jacot & Siculobata sicula Grandjean & Leaves & + \\
\hline
\end{tabular}

$+++=$ High population $\quad++=$ Moderate population $\quad+=$ Low population

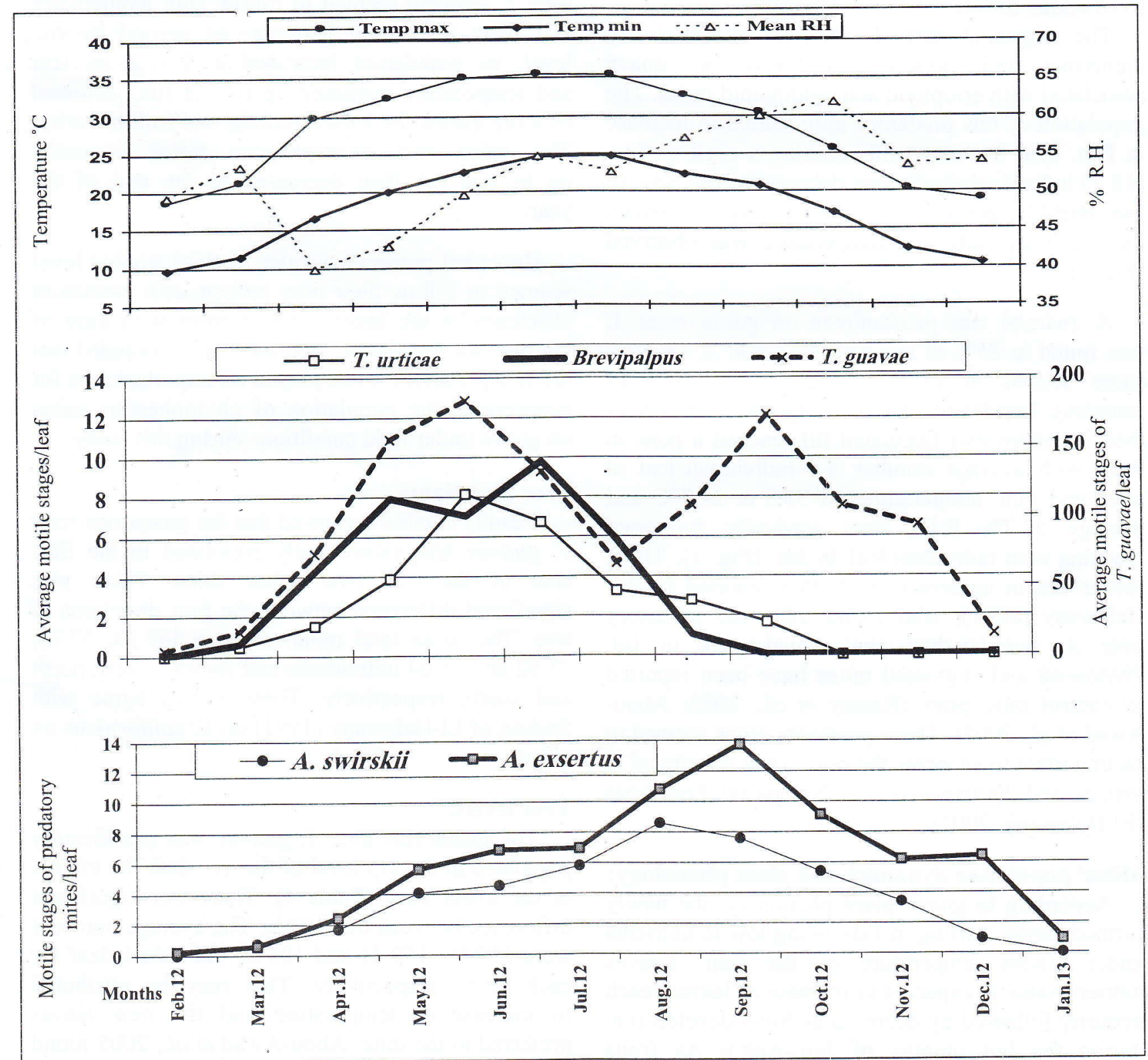

Fig. (1): Population abundance of predaceous mites inhabiting guava from Feb. 2012 to Jan. 2013 at Qalyoubia Governorate. 
Table (2): Correlation coefficient between temperature, relative humidity and mite populations in guava orchards over study period

\begin{tabular}{|c|c|c|c|}
\hline \multirow{3}{*}{ Mite species } & \multicolumn{3}{|c|}{$\begin{array}{l}\text { Correlation Coefficient } \\
\text { values }\end{array}$} \\
\hline & Max & Min & Mean \\
\hline & Temp. & Temp. & R. H \\
\hline T. guavae & $0.72 * *$ & $0.72 * *$ & 0.08 \\
\hline T. urticae & $0.82 * *$ & $0.77 * *$ & -0.18 \\
\hline B. phoenicis on leaves & $0.77 * *$ & $0.68 *$ & -0.45 \\
\hline B. phoenicis on fruit & $0.83^{* *}$ & $0.61^{*}$ & 0.24 \\
\hline A. swirskii & $0.87 * * *$ & $0.93^{* * *}$ & 0.26 \\
\hline A. exsertus & $0.69 *$ & $0.80 * *$ & 0.39 \\
\hline
\end{tabular}

\section{Predacious mites:}

The stigmaeid mite $A$. exsertus was relatively numerous and widely distributed on guava associated with eriophyid and tenuipalpid mites. The population of this predatory mite started to increase in Feb. then fluctuated till reaching a peak in Sep. (13.75 individuals/leaf), then decreased from Nov. to Jan. Highly significant positive correlation between the predatory mite and temperature was observed (Fig. 1).

A. swirskii was predominant on guava trees. It was found in $85 \%$ ot the samples while $A$. exsertus came second in order of abundance $(50 \%$ of samples). Population started to appear in mid-May then increased and fluctuated till reached a peak in Aug. with average number 8.6 individuals/leaf at max. and min. temperatures of $35.3 \& 24.7^{\circ} \mathrm{C}$ and average $52.7 \%$ R.H., then gradually decreased reaching zero individual/leaf in Jan. (Fig. 1). These results are in agreement with that reported by ElHalawany (2001), who found that the predatory mite A. swirskii had one annual peak in Jul. Phytoseiid and stigmaeid mites have been reported to control mite pests (Rasmy et al., 2003; AbouAwad et al., 2005). These predatory mites seemed to be important to suppress the population density of $T$. urticae and Epitrimerus pyri Nalepa on Pear trees (El-Halawany, 2001).

Mites' population dynamics and plant phenology:

According to guava plant phenology, the newly formed leaves starting in Feb. being low in nutrients under lowest temperature of the year. Leaves nutrient value is expected to increase as leaves reach maturity followed by decrease as fruits develop (i.e. during the hot months of Jun.-Aug.). As fruits harvest occurs, leaves will increase in nutrient value and the tree efforts will be directed towards storage of nutrient for the new season.

Dynamics of phytophagous (especially eriophyid
Table (3): Preference of the eriophyid mite $T$. guavae to tree level, leave's surface and leave's age.

\begin{tabular}{|c|c|c|c|}
\hline Variable & Level & $\begin{array}{l}\text { Mean number of } \\
\text { mites/leaf }\end{array}$ & L.S.D \\
\hline \multirow{3}{*}{ Tree levels } & Top & $255.58 \mathrm{a}$ & \multirow{3}{*}{20.75} \\
\hline & Middle & $150.41 \mathrm{~b}$ & \\
\hline & Low & $105.83 c$ & \\
\hline \multirow{2}{*}{$\begin{array}{l}\text { Leaves } \\
\text { surface }\end{array}$} & Lower & $146.74 \mathrm{a}$ & \multirow{2}{*}{6.67} \\
\hline & Upper & $41.93 \mathrm{~b}$ & \\
\hline \multirow{2}{*}{ Leave age } & New & $145.47 \mathrm{a}$ & \multirow{2}{*}{6.67} \\
\hline & Old & $43.19 b$ & \\
\hline
\end{tabular}

Means with the same letter within the same variable is not significantly different $(\mathrm{P}>0.05)$.

mite $T$. guavae) seemed to follow both temperature and plant phenology patterns. As second trophic level, its population increased as leaves nutrient and temperature increased up to mid-Jun. followed by a dip during the hottest months and fruit maturity. The other two phytophagous mites increased up to mid-Jul. then decreased to the end of the year.

Recorded predacious mites as third trophic level seemed to follow their prey pattern with maximum efficiency at the higher temperatures with kind of lag time for population increase. This concluded that the two predatory mites played an important role for suppressing the population of phytophagous mites on guava under field conditions during this study.

\section{Tree directions:}

Results in table 3 showed that the guava rust mite $T$. guavae was significantly populated in the East side of the tree over other sides. There was significant difference between the four directions of tree. The mean total numbers were $147.58,57.79$, 73.92 and 98.04 individuals/leaf for east, west, north and south, respectively. These results agree with finding of El-Halawany (1991) on B. californicus on citrus.

\section{Tree levels:}

The guava rust mite $T$. guavae was significantly populated in the top level of the tree than the middle or the lower ones (Table 4). There was significant difference between tree levels. The average numbers were $255.58 ; 150.41$ and 105.83 individuals/leaf for each level, respectively. This may be attributed to increase of temperature and the new leaves preferred to the mite. Abou-Awad et al., 2005 found the mean number of $T$. hassani per leaf was high on leaves on top and middle leaves of olive bushes. At the bottom level, leaves had relatively less numbers of species in comparison to the top and middle levels. 


\section{Leaves age and surfaces:}

The guava rust mite $T$. guavae was significantly populated on the newly leaves than the old ones (Table 3). The mean number of mites was 145.47 and 43.19 individuals/leaf for new and old ones, respectively. T. guavae was significantly populated on the lower surface than upper one. This result agree with the finding of El-Halawany, 2001 on Aceria ficus (Cotté) on fig trees.

\section{REFERENCES}

Abou-Awad, B. A.; Metwally, A. M. and Al-Azzazy, M. M. 2005. Environmental management and biological aspects of two eriophyid olive mites in Egypt: Aceria oleae (Nalepa) and Tegolophus hassani (Keifer). Z. Pflanzenkrankh. Pflanzensch., 112 (3): 287-303.

El-Halawany, A.S. 2001. Studies on some mite species infesting sume fruit trees. M. Sc. Thesis, Fac. Agric. Moshtohor, Benha Branch, Zagazig Univ., $164 \mathrm{pp}$.

El-Halawany, A.S. 2012. Survey of eriophyid mites on some fruit trees, with re-descriptions of two newly recorded species and a checklist of eriophyid mites in Egypt (Acari: Eriophyoidea). Egypt. Acad. J. biolog. Sci., 5 (2):205 -216.

El-Halawany, M. E. 1991. Some factors affecting the distribution of Brevipalpus californicus (Banks) on citrus trees. Egypt. J. Agric. Res., 69 (1): 185-192.

Ghoshal, S.; Barman, S. and Saha, M. 2011. Seasonal abundance and feeding efficiency of the false spider mite Tenuipalpus pernicis (Chaudhri,
Akbar and Rasool) on guava (Psidium guajava). Acarina, 19(2): 265-269.

Jeppson, L. R.; Keifer, H. H and Baker, E. W. 1975. - Mites injurious to economic plants. University of California Press, California, 614 pp.

Quirós, M.; Poleo, N. and Petit, Y. 2002. Evaluation of damage at the apex fruit Psidium guajava L., caused by Brevipalpus phoenicis (Geijskes) (Acari: Tenuipalpidae). Entomotropica, 17: 9196.

Pena, J. E.; Duncan, R. and Vasquez, T. 1999. Guava arthropod seasonality and control of fruit files in South Florida. Proc. Fla. State Hort. Soc., 112: 206-209.

Rasmy, A. H.; Momen, F. M.; Zaher, M. A. and Abou-Elela, G. M. 2003. Influence of diet on life history and predatory capacity of Amblyseius zaheri Yousef and El-Borlossy (Acari: Phytoseiidae). Insect Sci. Applic., 23: 31-34.

Sarwar, M. 2006. Occurrence of insect pests on guava (Psidium guajava) Tree. Pakistan J. Zool., 38(3):197-200.

SAS Institute, 2010. SAS Statistics and Graphics Guide, Release 9.1. SAS Institute, Cary, North - Carolina 27513, USA.

Zaher, M. A. 1984. Survey and ecological studies on phytophagous, predaceous and soil mites in Egypt. I: Phytophagous mites in Egypt (Nile valley and Delta). PI- 480 Programme. USA Project No. EG. ARS, 30. Grant. No, FG, Eg., 1-181pp.

Zaher, M. A. and Gomaa, E.A. 1979. Genus Neophyllobius in Egypt with description of three new species (Prostigmata: Neophyllobiidae). Inter. J. Acarol., 5(2): 123-130. 